\title{
Are there factors in the disease of peroneal necrotizing fasciitis which should be used when choosing the anesthetic technique?: Descriptive analysis of a cohort from two centers
}

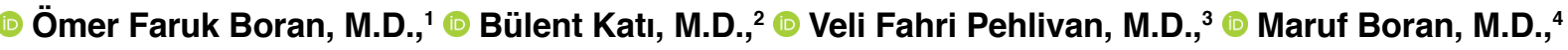 \\ Evren Büyükfırat, M.D., ${ }^{3} \odot$ Mehmet Buğra Bozan, M.D., ${ }^{5} \odot$ Osman Barut, M.D., ${ }^{6}$ \\ Mehmet Kutlu Demirkol, M.D., ${ }^{6}$ ๑ Halil Çiftçi, M.D. ${ }^{2}$
}

\begin{abstract}
1'Department of Anesthesiology and Reanimation, Kahramanmaraş Sütçü İmam University Faculty of Medicine, Kahramanmaraş-Turkey ${ }^{2}$ Department of Urology, Harran University Faculty of Medicine, Şanlıurfa-Turkey ${ }^{3}$ Department of Anesthesiology and Reanimation, Harran University Faculty of Medicine, Şanlıurfa-Turkey ${ }^{4}$ Department of Intensive Care Unit, Amasya Şerefeddin Sabuncuoğlu Training and Research Hospital, Amasya-Turkey ${ }^{5}$ Department of General Surgery, Kahramanmaraş Sütçü İmam University Faculty of Medicine, Kahramanmaraş-Turkey ${ }^{6}$ Department of Urology, Kahramanmaraş Sütçü Imam University Faculty of Medicine, Kahramanmaraş-Turkey
\end{abstract}

\section{ABSTRACT}

BACKGROUND: This study aims to examine the factors affecting the selection of anaesthesia method in Fournier's gangrene.

METHODS: A retrospective evaluation was made of I I 3 patients operated on because of Fournier's gangrene between January-May 2019. The operations were performed under spinal anaesthesia in 78 cases (Group S) and under general anaesthesia in 35 cases (Group $\mathrm{G})$. The patients were evaluated regarding age, gender, the anaesthesia method used (spinal, general) anaesthetic agent applied, presence of sepsis, and biochemical, hematological and inflammatory parameters.

RESULTS: When the patients were evaluated regarding the Fournier Gangrene Severity Index (FGSI), patients in Group S had lower scores $(p=0.00 I)$. Examination of the tomography images revealed that in $13(37.1 \%)$ patients, air values were seen in the right or left gluteal area, or both, extending to the subcutaneous tissue. In the evaluation of the factors affecting the selection of general anaesthesia, a positive correlation was determined between an increase in FGSI $(r=0.482, p=0.001)$ and the presence of sepsis $(r=0.485$, $\mathrm{p}=0.00 \mathrm{I})$ and gluteal region involvement $(r=0.628, \mathrm{p}<0.00 \mathrm{I})$.

CONCLUSION: The selection of anaesthesia method in Fournier gangrene patients is a complex process affected by factors, such as the patients' general condition, sepsis, and whether or not there is bleeding diathesis. The risk -benefit balance in the selection of anaesthesia method should be evaluated individually for patients.

Keywords: Anaesthesia method; Fournier's gangrene; sevoflurane; TIVA; ultiva.

\section{INTRODUCTION}

Fournier's gangrene, which was first described in 1883 by Jean Alfred Fournier as "gangraena acuta genitalium", is defined as an infective necrotisng fasciitis table, with an acute onset and progressive and potentially fatal course, affecting the external genital and/or perianal regions, usually of males. Despite improvements in intensive care conditions and the use of new

Cite this article as: Boran Ö, Katı B, Pehlivan VF, Boran M, Büyükfırat E, Bozan MB, et al. Are there factors in the disease of peroneal necrotizing fasciitis which should be used when choosing the anesthetic technique?: Descriptive analysis of a cohort from two centers. Ulus Travma Acil Cerrahi Derg 2022;28:48-56.

Address for correspondence: Ömer Faruk Boran, M.D.

Kahramanmaraş Sütçü İmam Üniversitesi Tıp Fakültesi, Anestezi ve Reanimasyon Anabilim Dalı, Kahramanmaraş, Turkey

Tel: +90 344 - 3003434 E-mail: ofboran@ksu.edu.tr

Ulus Travma Acil Cerrahi Derg 2022;28(I):48-56 DOI: 10.14744/tites.2020.15088 Submitted: 05.01.2020 Accepted: 12.05.2020

Copyright 2022 Turkish Association of Trauma and Emergency Surgery 
generation antibiotic agents, mortality remains extremely high at $30 \%-40 \%$ due to the rapid spread of the disease by necrosis forming in the fascial planes and that it is generally caused by multiple micro-organisms. ${ }^{[1]}$

There are several reports in the literature that have evaluated factors related to the etiopathogenesis of the disease, treatment modalities, morbidity and mortality, ${ }^{[2-4]}$ but there have been very few studies that have evaluated this particular patient group regarding anaesthesia method in the literature. ${ }^{[5-7]}$

Anaesthesia management for patients undergoing surgery because of Fournier's gangrene is usually challenging due to the destructive nature of the disease, significant comorbid diseases, the need for repeated operations and the possibility of an accompanying septic table. ${ }^{[8]}$ There are some studies in the literature related to the effects on the immune system functions of general and spinal anaesthesia applications, and there are also some studies that have evaluated the effects of different volatile general anaesthesia agents on the immune system functions. ${ }^{\left[{ }^{[9]}\right.}$ If there is any infectious state in the area where anaesthesia is to be applied, there may be severe complications, including spread to the intraspinal canal and hemodynamic and cardiac function instability, so spinal anaesthesia is another method that can be safely used in FG patients. From a scan of the literature, three studies have been found that have evaluated anaesthesia applications in FG patients and all of these publications are in the form of case reports. ${ }^{[5-7]}$

It has been understood from these articles that clinicians may select general, regional or local anaesthesia methods in the anaesthesia management of FG patients. However, to our knowledge, there is no study in English that has evaluated the factors affecting the clinician's decision of which method to apply. It can be considered that an evaluation of the factors affecting the selection of anaesthesia method in these particular types of cases will contribute to the literature, be of guidance in the selection of the anaesthesia method and could be useful in reducing anaesthesia complications that may develop.

The present study aims to examine the factors which could affect the choice of anaesthetic method to be used in patients with Fournier's gangrene.

\section{MATERIALS AND METHODS}

\section{Setting and Patients}

Approval for thid study was granted by the Local Ethics Committee (2019/04/12). A retrospective evaluation was made of 128 patients treated surgically for Fournier's gangrene between January 2014 and May 2019. The patients were from two separate tertiary level anaesthesia intensive care units, each of which has 20 beds and treat an average of $1200 \mathrm{pa}-$ tients per year, and from tertiary level general surgery and urology clinics where an average of 800 emergency operations per year are performed. The data were collected from patient files, computer records, surgical records and anaesthesia forms.

After the exclusion of 15 patients with unavailable data, I I 3 patients were included in this study. Patients were classified as those with operations performed under spinal anaesthesia ( $n=78$, Group $S)$ or general anaesthesia ( $n=35$, Group $G)$. The patients in Group $G$ were then separated into two subgroups according to the type of general anaesthesia; TIVA, Group $T(n=24)$ and Ultiva-sevoflorane, Group US $(n=I I)$. All procedures were performed under emergency conditions. Informed consent was obtained from the patients and first-degree relatives before the procedures were applied.

\section{Preoperative Evaluation, Anaesthesia Application and Surgical Procedure}

All the patients were evaluated in the Emergency Polyclinic by a general surgeon and/or an urologist. In the preoperative and postoperative periods, evaluations were made regarding inflammatory markers, hematological parameters and biochemical parameters. Radical surgical excision was made of tissues seen to be necrotic macroscopically with a debridement process until healthy tissue was reached (Table 2).

Depending on the severity and spread of the disease during the operation, colostomy procedures were applied to patients requiring colostomy by the general surgery team. Tissue cultures taken interoperatively were sent immediately to the microbiology laboratory. For patients who were not hemodynamically stable, fluid replacement was started preoperatively and was continued via a central venous catheter placed intraoperatively to maintain urine output at $0.5-\mathrm{lcc} /$ $\mathrm{kg} / \mathrm{hour}$, mean arterial pressure at $65 \mathrm{mmHg}$ and/or central venous pressure $8-12 \mathrm{mmHg}$. Vasopressor and inotropic agents were used in patients where the target values could not be reached with sufficient crystalloid solution. In patients with hematocrit values $<30 \%$, erythrocyte suspension was administered to try to raise the hematocrit value to $>30 \%$.

In the postoperative period, empirical ceftriaxone at $4 \mathrm{gr} /$ day and metronidazole at $1.5 \mathrm{gr} /$ day were administered until the culture results were received. The antibiotic treatments were then revised according to the culture results. In cases where wound site infection spread was observed or for those who were not hemodynamically stable, surgical resection was applied again under operating room conditions.

The Fournier Gangrene Severity Index (FGSI) is a scoring system, including different clinical and laboratory parameters, such as temperature, pulse, respiratory count, sodium, potassium, creatinine, leukocyte, hematocrit and bicarbonate. Within this scoring system, points are given from $0-4$ ac- 
Table I. Preoperative and postoperative values of the hematological, biochemical and inflammatory parameters of the patients applied with spinal anaesthesia and general anaesthesia

\begin{tabular}{|c|c|c|c|c|c|c|}
\hline \multirow[t]{2}{*}{ Variables } & \multirow{2}{*}{$\frac{\text { Group } S(n=78)}{\text { Preoperative value }}$} & \multirow{2}{*}{$\frac{\text { Group G }(n=35)}{\text { Preoperative value }}$} & \multirow[t]{2}{*}{$\mathbf{p}$} & \multirow{2}{*}{$\frac{\text { Group S }(n=78)}{\text { Postoperative value }}$} & \multirow{2}{*}{$\frac{\text { Group G }(n=35)}{\text { Postoperative value }}$} & \multirow[t]{2}{*}{$\mathbf{p}$} \\
\hline & & & & & & \\
\hline WBC & $16.46 \pm 6.63$ & $|6.36 \pm| 0.3 \mid$ & 0.822 & $12.58 \pm 4.70$ & $14.75 \pm 8.26$ & 0.043 \\
\hline $\mathrm{Hb}$ & $|3.97 \pm||.0|$ & $11.76 \pm 2.58$ & 0.277 & $11.62 \pm 2.29$ & $11.01 \pm 2.26$ & 0.247 \\
\hline Plt & $311.02 \pm 156.13$ & $237.11 \pm 142.48$ & 0.019 & $345.29 \pm 147.45$ & $253.53 \pm 145.68$ & 0.003 \\
\hline CRP & $|82.36 \pm| \mid 4.50$ & $128.58 \pm 105.20$ & 0.260 & $44 . I I \pm 77.44$ & $85.77 \pm 1 \mid 1.81$ & 0.017 \\
\hline ALT & $30.13 \pm 26.42$ & $25.65 \pm 36.36$ & 0.485 & $26.69 \pm 25.30$ & $18.26 \pm 12.32$ & 0.078 \\
\hline AST & $33.17 \pm 23.38$ & $36.97 \pm 41.76$ & 0.499 & $30.38 \pm 26.48$ & $28.23 \pm 22.29$ & 0.767 \\
\hline BUN & $45.86 \pm 37.22$ & $46.65 \pm 42.91$ & 0.841 & $31.16 \pm 27.65$ & $34.38 \pm 38.06$ & 0.594 \\
\hline Cre & $1.22 \pm 1.20$ & $1.26 \pm 0.98$ & 0.750 & $0.87 \pm 0.88$ & $0.97 \pm 0.68$ & 0.495 \\
\hline Glu & $216.28 \pm 155.98$ & $190.95 \pm 117.73$ & 0.382 & $134.43 \pm 69.76$ & $150.66 \pm 73.45$ & 0.375 \\
\hline $\mathrm{Na}$ & $|36.5| \pm 5.38$ & $134.97 \pm 5.22$ & 0.121 & $136.89 \pm 69.76$ & $137.52 \pm 4.24$ & 0.556 \\
\hline K & $4.33 \pm 0.61$ & $4.14 \pm 0.73$ & 0.146 & $4.24 \pm 0.60$ & 4. $10 \pm 0.63$ & 0.300 \\
\hline $\mathrm{HCO} 3$ & $20.97 \pm 4.37$ & $20.91 \pm 3.81$ & 0.961 & $23.15 \pm 2.20$ & $23.07 \pm 3.56$ & 0.935 \\
\hline Lactate & $2.55 \pm 1.96$ & $2.67 \pm 1.93$ & 0.722 & $1.24 \pm 0.88$ & $1.90 \pm 1.98$ & 0.123 \\
\hline Pulse & $97.42 \pm 15.20$ & $100.09 \pm 15.4 \mid$ & 0.475 & $88.60 \pm 11.05$ & $89.67 \pm 12.26$ & 0.568 \\
\hline Respiratory rate & $|8.73 \pm 3.8|$ & $|8.83 \pm 3.6|$ & 0.961 & $16.80 \pm 2.56$ & $16.12 \pm 2.20$ & 0.217 \\
\hline Saturation & $96.19 \pm 2.70$ & $96.67 \pm 2.32$ & 0.287 & $97.69 \pm 2.05$ & $98.09 \pm 2.03$ & 0.340 \\
\hline
\end{tabular}

ALT: Alanine aminotransferase; AST: Aspartate aminotransferase; BUN: Blood urea nitrogen; CRP: C-reactive protein; Glu: Blood glucose; Hb: Hemoglobin; HCO3: Bicarbonate; K: Potassium; Cre: Creatinine; Na: Sodium; Plt: Platelet; WBC: White blood cell.

cording to the level of deviation from normal values of each parameter and the FGSI score is determined with the total points obtained. ${ }^{[10]}$ For each patient in this study, the FGSI score was calculated taking the clinical and laboratory parameters into consideration.

All the patients were evaluated regarding age, gender, comorbid diseases, the anatomic area affected (perianal, scrotal, perianal+scrotal), complications, the anaesthesia method used (spinal, general), the anaesthetic agent used and dose, amount of fluid given intraoperatively, duration of anaesthesia, presence of sepsis, preoperative and postoperative biochemical, hematological and inflammatory parameters, postoperative status in the ward or ICU, length of stay in the hospital and discharge status (discharged home with medication, exitus).

\section{Anaesthesia Procedures}

\section{General Anaesthesia Procedure}

General anaesthesia was applied to patients with contraindication for spinal anaesthesia, such as suspicion of infection having advanced to the gluteal area, bleeding diathesis, septic shock table, severe heart disease-causing hemodynamic instability, or if they did not accept spinal anaesthesia. The anaesthesia was applied as follows: in induction, propofol (2 $\mathrm{mg} / \mathrm{kg})$ and fentanyl $(\mathrm{I}-3 \mu \mathrm{gr} / \mathrm{kg})$ were used as intravenous agents and rocuronium $(0.6 \mathrm{mg} / \mathrm{kg})$ or atracurium $(0.6 \mathrm{mg} / \mathrm{kg})$ as muscle relaxants. For anaesthesia maintenance throughout the operation, total intravenous anaesthesia (TIVA) was applied using 9-12 mg/kg propofol and 0.2-0.5 mg/kg/min ultiva bispectral index (BIS) monitorization, or $0.2-0.5 \mathrm{mg} / \mathrm{kg} / \mathrm{min}$ ultiva and sevoflurane with BIS at 40-60. Mechanical ventilator parameters were set equivalent to the optimum PEEP value for driving pressure to be $<12$. Contramal+paracetamol was used as postoperative analgesia taking organ functions into consideration.

\section{Spinal Anaesthesia Procedure}

Spinal anaesthesia was applied to patients with no suspected infection in the application area, no bleeding diathesis, no septic shock table, no severe heart disease-causing hemodynamic instability and acceptance of spinal anaesthesia. When patients were admitted to the operating table, first non-invasive blood pressure, ECG, pulse oximetry $\left(\mathrm{SpO}_{2}\right)$ and body temperature monitorisation were applied; then sedation was administered as $2 \mathrm{mg}$ midazolam IV. The patient was positioned lateral decubitus and the area where the anaesthesia was to be applied was evaluated regarding infection. The spinal anaesthesia was applied to the L3-4 space with 0.5\% hyperbaric bupivacaine using a $27 \mathrm{G}$ spinal needle, and the patient was then placed in the lithotomy position. Intraoperatively $\mathrm{O}_{2}$ was administered at 2-4 lt/min from a nasal cannulla and patients with $\mathrm{SpO}_{2}<90$ were applied with continuous positive airway pressure (CPAP). As standard monitoring, heart rate 
(HR), systolic (SAP), diastolic (DAP) and mean (MAP) arterial blood pressures, peripheral arterial oxygen saturation $\left(\mathrm{SpO}_{2}\right)$, end-tidal carbon dioxide concentration (etCO $\mathrm{CO}_{2}$ ), body temperature with an esophageal heat probe, percent (\%) concentrations of inspired-exported anesthetic gas (inspirium and expirium) and applied anesthetic gas were recorded. Bispectral index monitoring (with BIS-VISTA Covidien monitor) was performed in addition to patients receiving general anesthesia before induction. The BIS electrodes are placed $1.5-2 \mathrm{~cm}$ above the first electrode $1.5-2 \mathrm{~cm}$ between the two eyes, the $2^{\text {nd }}$ electrode is placed to the right or the left in the middle of the distance between the hair and the eye, and the third electrode is placed between them, device calibration and contact test of the electrodes is completed. Then the measured BIS value was recorded. It is reported that the amount of anesthetic agent to be applied to the patient can be reduced by titration, faster recovery can be achieved, and the duration of postoperative intensive care can be shortened by monitoring the bispectral index (BIS).

A urine catheter was inserted in all patients in the preoperative period. Central venous catheter was placed in patients who were hemodynamically unstable and clinically considered sepsis in the preoperative period, and central venous pressure measurements were made, and patients were monitored. Also, arterial blood gas measurements were made where necessary.

The primary fluid preference in the patients was in the form of ringer lactate according to saline or liver enzyme status. However, it has been used in colloid solutions in hypotensive patients requiring fluid restriction or in patients with a fluid deficit that cannot be met with crystalloid. Blood replacement was performed in patients whose $\mathrm{Hb}$ level decreased below $10 \mathrm{~g} / \mathrm{dL}$ in the complete blood count measured during debridement or in patients with $\mathrm{Hb}$ levels $10 \mathrm{~g} / \mathrm{dL}$ despite the absence of any chronic disease (e.g., CKD).

\section{Statistical Analysis}

Data obtained in this study were analysed statistically using SPSS I7.0 software (SPSS Inc., Chicago, IL, USA). Conformity of the data to normal distribution was tested with the Shapiro-Wilk test and variance homogeneity with the Levene test. In the comparison of two independent groups, the Independent Samples t-test was used with Bootstrap results and the Mann Whitney U-test with the Monte Carlo simulation technique. One-way ANOVA analysis with the post-hoc Tukey HSD test was used in the comparison of multiple groups. In the comparison of categorical data, the Pearson Chi-square and Fisher Exact tests were applied with the Monte Carlo simulation technique. Quantitative data were stated in the tables as mean \pm standard deviation (SD) and median (minimum-maximum) values, and categorical data as number ( $n$ ) and percentage (\%). A value of $p<0.05$ was accepted as statistically significant.

\section{RESULTS}

Of the 113 patients included in this study, Group S comprised $70(61.9 \%)$ males and 28 females with a mean age of $57.49 \pm 15.69$ years, and Group G comprised 26 (I2.5\%) males and nine females with a mean age of $50.97 \pm 17.69$ years. When the patients were evaluated regarding the length of stay in ICU, the patients in Group $S$ spent a significantly shorter period in ICU ( $p=0.032)$. The Group $S$ patients had statistically significantly lower FGSI scores than Group $G$ patients $(p=0.00 \mathrm{I})$. The demographic and surgical data of the patients are shown in Table 2.

In the evaluation of the hematological, biochemical and inflammatory parameters, the CRP values of Group $S$ were observed to have fallen significantly more in the postoperative period compared to those of Group $G(p=0.017)$. No statistically significant difference was determined between the groups regarding any other parameters $(p>0.05)$.

In the evaluation of the subgroups of the general anaesthesia group, the TIVA group (Group T) comprised 24 (68.6\%) patients and the Ultiva+sevoflurane group (Group US) II (3I.4\%) patients. No difference was determined between these two groups regarding preoperative hematological, biochemical and inflammatory parameters $(p>0.05)$ (Table 3$)$. In the evaluation of the postoperative biochemical and hematological data according to anaesthesia, the WBC, CRP, BUN and creatinine values of Group US were determined to be statistically significantly higher than those of the other groups (Group $S$ and Group T) ( $p=0.023, p=0.020, p=0.047$, $p=0.042$, respectively) (Table 4).

Tomographic examination was made of $87(77 \%)$ patients in the preoperative period. Of these patients applied with CT, 53 (46.9\%) received spinal anaesthesia and 34 (30.1\%) general anaesthesia. When the CT images were examined of the patients in Group G, there was no paravertebral area involvement in any patient. However, in $40 \%$ patients, there were reported to be lesion areas of heterogenous soft tissue density observed as air values starting from the perianal region and continuing along the gluteal sulcus and within one or both of the right or left gluteal areas extending to the subcutaneous tissue. It was seen that spinal or local anaesthetic was not applied to any patient showing gluteal region extension.

The factors affecting the selection of anaesthesia method in the patients evaluated in the study are shown in Table 5 . When the factors affecting the selection of general anaesthesia were examined, a positive correlation was determined between an increase in the FGSI score $(r=0.482, p=0.001)$, the presence of sepsis $(r=0.485, p=0.00 \mathrm{I})$ and gluteal region involvement $(r=0.628, p<0.00 I)$. A positive correlation was determined between a decrease in platelet values and the application of spinal anaesthesia $(r=0.238, p=0.0 \mathrm{I})$. 
Table 2. Demographic characteristics and medical conditions of the study population $(n=1 \mid 3)$

\begin{tabular}{|c|c|c|c|}
\hline Variables & Group $S(n=78)$ & Group G $(n=35)$ & $\mathbf{p}$ \\
\hline Age (years) & $57.49 \pm 15.69$ & $50.97 \pm 17.69$ & 0.131 \\
\hline Gender (male), n (\%) & 70 (61.9) & $26(23)$ & 0.046 \\
\hline \multicolumn{4}{|l|}{ Comorbid disease, n (\%) } \\
\hline No comorbidity & $36(32.2)$ & $14(12.5)$ & 0.384 \\
\hline Diabetes mellitus & $8(7.1)$ & $7(6.2)$ & \\
\hline Cardiovascular & $7(6.2)$ & I (0.9) & \\
\hline Active cancer/chemotherapy & $0(0.0)$ & $2(1.8)$ & \\
\hline HIV infection & $\mathrm{I}(0.9)$ & $0(0.0)$ & \\
\hline Chronic steroid use & $2(1.8)$ & $0(0.0)$ & \\
\hline Diabetes mellitus+Chronic renal failure & $24(21.4)$ & $10(9.0)$ & \\
\hline Time from onset of symptoms to presentation (days) & $7.77 \pm 6.41$ & $6.20 \pm 5.91$ & 0.371 \\
\hline Length of stay in hospital (days) & $|7.6| \pm 15.23$ & $21.02 \pm|4.2|$ & 0.438 \\
\hline Length of stay in ICU (days) & $3.68 \pm 10.40$ & $8.97 \pm 15.21$ & 0.032 \\
\hline Length of stay in ward (days) & $13.65 \pm 11.32$ & $\mid 1.71 \pm 9.47$ & 0.326 \\
\hline Duration of antibiotic use (days) & $15.84 \pm 1 \mid .83$ & $19.38 \pm 11.47$ & 0.325 \\
\hline Fournier's gangrene severity index & $3.19 \pm 2.70$ & $6.82 \pm 3.81$ & 0.001 \\
\hline Duration of surgery (mins) & $71.39 \pm 34.98$ & $94.35 \pm 43.21$ & 0.006 \\
\hline Number of operations & $1.27 \pm 0.7 \mid$ & $1.20 \pm 0.47$ & 0.514 \\
\hline Mortality, n (\%) & $2(2.7)$ & $3(8.5)$ & 0.342 \\
\hline
\end{tabular}

Table 3. Preoperative and postoperative values of the hematological, biochemical and inflammatory parameters of the patients applied with different general anaesthesia techniques

\begin{tabular}{|c|c|c|c|c|c|c|}
\hline \multirow[t]{2}{*}{ Variables } & \multirow{2}{*}{$\frac{\text { Group-T }(n=24)}{\text { Preoperative value }}$} & \multirow{2}{*}{$\frac{\text { Group US }(n=I I)}{\text { Preoperative value }}$} & \multirow[t]{2}{*}{$\mathbf{p}$} & \multirow{2}{*}{$\frac{\text { Group T }(n=24)}{\text { Postoperative value }}$} & \multirow{2}{*}{$\frac{\text { Group US }(n=I I)}{\text { Postoperative value }}$} & \multirow[t]{2}{*}{$\mathbf{p}$} \\
\hline & & & & & & \\
\hline WBC & $16.46 \pm 6.63$ & $|6.36 \pm| 0.3 \mid$ & 0.935 & $13.44 \pm 7.47$ & $|7.6| \pm 9.5 \mid$ & 0.023 \\
\hline $\mathrm{Hb}$ & $11.69 \pm 2.64$ & $11.92 \pm 2.58$ & 0.964 & $11.13 \pm 2.53$ & $10.74 \pm 1.53$ & 0.852 \\
\hline Plt & $24 \mid .16 \pm 142.63$ & $228.28 \pm \mid 48.68$ & 0.808 & $264.13 \pm 145.89$ & $228.10 \pm 149.67$ & 0.519 \\
\hline CRP & $95.45 \pm 123.47$ & $|27.6| \pm \mid 43.93$ & 0.237 & $71.39 \pm 93.45$ & $120.29 \pm 147.12$ & 0.251 \\
\hline ALT & $19.66 \pm 17.60$ & $38.72 \pm 59.24$ & 0.292 & $19.00 \pm 12.32$ & $16.50 \pm 12.79$ & 0.598 \\
\hline AST & $28.58 \pm 31.42$ & $55.27 \pm 55.87$ & 0.090 & $24.00 \pm 12.38$ & $38.40 \pm 35.60$ & 0.086 \\
\hline BUN & $45.50 \pm 48.33$ & $55.27 \pm 55.87$ & 0.112 & $27.50 \pm 14.96$ & $50.90 \pm 65.66$ & 0.103 \\
\hline Cre & $1.22 \pm 1.20$ & $1.26 \pm 0.98$ & 0.895 & $0.82 \pm 0.47$ & $1.34 \pm 0.97$ & 0.046 \\
\hline Glu & $190.75 \pm 132.87$ & $191.36 \pm 80.76$ & 0.978 & $190.95 \pm 117.73$ & $134.43 \pm 69.76$ & 0.314 \\
\hline $\mathrm{Na}$ & $134.54 \pm 3.92$ & $135.90 \pm 7.47$ & 0.768 & $136.97 \pm 55.22$ & $|38.90 \pm 60.8|$ & 0.230 \\
\hline K & $4.10 \pm 0.76$ & $4.24 \pm 0.70$ & 0.596 & $4.03 \pm 0.65$ & $4.27 \pm 0.60$ & 0.332 \\
\hline $\mathrm{HCO} 3$ & $23.20 \pm 3.53$ & $22.96 \pm 3.80$ & 0.264 & $23.20 \pm 3.53$ & $22.96 \pm 2.20$ & 0.899 \\
\hline Lactate & $1.38 \pm 0.57$ & $2.46 \pm 2.56$ & 0.162 & $1.38 \pm 0.57$ & $2.13 \pm 2.70$ & 0.665 \\
\hline Pulse & $103.42 \pm 15.47$ & $93.10 \pm 13.59$ & 0.081 & $88.19 \pm 9.97$ & $92.80 \pm 16.26$ & 0.336 \\
\hline Respiratory rate & $19.33 \pm 3.02$ & $17.80 \pm 4.63$ & 0.277 & $16.57 \pm 2.15$ & $15.20 \pm 2.09$ & 0.106 \\
\hline Saturation & $97.04 \pm 2.49$ & $95.90 \pm 1.79$ & 0.205 & $98.33 \pm 2.24$ & $97.60 \pm 1.50$ & 0.358 \\
\hline
\end{tabular}

ALT: Alanine aminotransferase; AST: Aspartate aminotransferase; BUN: Blood urea nitrogen; CRP: C-reactive protein; Glu: Blood glucose; Hb: Hemoglobin; HCO3: Bicarbonate; K: Potassium; Cre: Creatinine; Na: Sodium; Plt: Platelet; WBC: White blood cell. 
Table 4. Comparison of the postoperative biochemical and hematological parameters according to groups

\begin{tabular}{|c|c|c|c|c|}
\hline \multirow[t]{2}{*}{ Variables } & \multicolumn{3}{|c|}{ Postoperative value } & \multirow[t]{2}{*}{$\mathbf{p}$} \\
\hline & Group $S(n=78)$ & Group T $(n=24)$ & Group US $(n=I I)$ & \\
\hline White blood cell & $12.58 \pm 4.70$ & $13.44 \pm 7.47$ & $|7.6| \pm 9.5 \mid$ & 0.023 \\
\hline Hemoglobin & $11.62 \pm 2.29$ & $11.13 \pm 2.53$ & $10.74 \pm 1.53$ & 0.464 \\
\hline Platelet & $345.29 \pm 147.45$ & $264.13 \pm 145.89$ & $228.10 \pm 149.67$ & 0.003 \\
\hline C-reactive protein & 44. $I I \pm 77.44$ & $71.39 \pm 93.45$ & $120.29 \pm 147.12$ & 0.020 \\
\hline Alanine aminotransferase & $26.69 \pm 25.30$ & $19.00 \pm 12.32$ & $16.50 \pm 12.79$ & 0.204 \\
\hline Aspartate aminotransferase & $30.38 \pm 26.48$ & $24.00 \pm 12.38$ & $38.40 \pm 35.60$ & 0.287 \\
\hline Blood urea nitrogen & $31.16 \pm 27.65$ & $27.50 \pm 14.96$ & $50.90 \pm 65.66$ & 0.047 \\
\hline Creatinine & $0.87 \pm 0.88$ & $0.82 \pm 0.47$ & $1.34 \pm 0.97$ & 0.042 \\
\hline Blood glucose & $134.43 \pm 69.76$ & $190.95 \pm 117.73$ & $134.43 \pm 69.76$ & 0.142 \\
\hline Sodium & $136.89 \pm 69.76$ & $136.97 \pm 55.22$ & $|38.90 \pm 60.8|$ & 0.556 \\
\hline Potassium & $4.24 \pm 0.60$ & $4.03 \pm 0.65$ & $4.27 \pm 0.60$ & 0.348 \\
\hline Bicarbonate & $23.15 \pm 2.20$ & $23.20 \pm 3.53$ & $22.96 \pm 2.20$ & 0.982 \\
\hline Lactate & $1.24 \pm 0.88$ & $2.67 \pm 1.93$ & $1.24 \pm 0.88$ & 0.254 \\
\hline Pulse & $88.60 \pm 11.05$ & $100.09 \pm 15.4 \mid$ & $88.60 \pm 11.05$ & 0.489 \\
\hline Repiratory rate & $16.80 \pm 2.56$ & $|8.83 \pm 3.6|$ & $16.80 \pm 2.56$ & 0.157 \\
\hline Saturation & $97.69 \pm 2.05$ & $96.67 \pm 2.32$ & $97.69 \pm 2.05$ & 0.340 \\
\hline
\end{tabular}

Table 5. Evaluation of the factors related to the anaesthesia technique

\begin{tabular}{llc}
\hline & \multicolumn{2}{l}{ Anesthesia technique } \\
\cline { 2 - 3 } & \multicolumn{1}{r}{} & $\mathbf{p}$ \\
\hline Fournier's gangrene severity index & $0.482^{* *}$ & 0.001 \\
Platelet & $-0.238^{*}$ & 0.011 \\
Requirement for inotropic agent & $0.212^{*}$ & 0.026 \\
Extent of surgery & $0.212^{*}$ & 0.024 \\
Sepsis & $0.485^{* *}$ & 0.001 \\
Gluteal involvement & $0.628^{* *}$ & $<0.001$ \\
\hline
\end{tabular}

\section{DISCUSSION}

Despite improvements in intensive care conditions and the development of new antibiotic agents, surgical debridement still constitutes the basis of FG treatment. ${ }^{[I-3, I]]}$ It has been reported that there was an accompanying sepsis table in approximately $40 \%$ of patients. ${ }^{\left[{ }^{\prime \prime}\right]}$ The selection of anaesthesia method for septic patients is important because of complications that may develop postoperatively, such as immune suppression, acute renal failure and cardiac depression. However, no consensus has been reached on which anaesthesia method should be selected for which patients.

A thorough preoperative preoperative evaluation of the patient and the prediction and prevention of complications that could occur intraoperatively and postoperatively are essential for the application of anaesthesia. ${ }^{[2]}$ In some studies, some diseases that cause an immune system failure (such as DM) have been reported to increase susceptibility to FG. ${ }^{[13-15]}$ In the current study, $55.7 \%$ of the patients had one or more comorbid diseases. When evaluated concerning comorbidities, the most significant was seen to be DM in $43.4 \%$ of the current study patients, followed by other pathologies, namely chronic renal failure (CRF) and cardiac diseases. The results of the current study were consistent with previous findings in the literature regarding the evaluation of comorbid diseases. However, when evaluated regarding factors related to mortality, there was not seen to be any relationship between DM and other comorbid diseases and mortality.

The spread of the disease has been reported to be an independent and the most important risk factor for mortality in FG patients. ${ }^{[16]}$ The FGSI is an objective scoring system that has been developed to predict disease severity and prognosis in patients with Fournier's gangrene. ${ }^{[10]}$ Previous studies have shown conflicting results concerning the relationship between FGSI score and mortality. Although some studies have reported a higher mortality rate in patients with a high FGSI score, ${ }^{[17,18]}$ other studies have emphasised that there is no relationship between FGSI score and mortality. ${ }^{[19,20]}$ In the current study, there was a strong positive correlation between FGSI score and mortality $(r=0.289, p=0.002)$. In addition, the findings obtained in this study demonstrated that the FGSI scores of the spinal anaesthesia group $(3.19 \pm 2.70)$ 
were statistically significantly lower than those of the general anaesthesia group $(6.82 \pm 3.8 \mathrm{I})(\mathrm{p}<0.00 \mathrm{I})$ and there was a strong positive correlation between an increase in total FGSI score and the application of general anaesthesia $(r=0.482$, $p=0.00 \mathrm{I})$. When the subgroups were analysed regarding the relationship between the anaesthesia method and the data forming the FGSI score, no single factor alone had a significant association with the selection of anaesthesia method. thereto our knowledge, there were no data in the literature about correlations between the FGSI score and anaesthesia application, no comparisons could be made with the current study results (Fig. I).

The use of CT in FG diagnosis is controversial. While some authors have emphasised that time is lost with the taking of CT and there could be disease progression, others have stated that by evaluating superficial and deep fascia structures with CT, the degree of necrosis can be revealed, which cannot be fully determined in physical examination, and this can be of guidance in determining the extent of resection and could determine the etiological factor causing the development of FG. ${ }^{[21,22]}$ That the use of CT could be of guidance in the selection of the anaesthesia method was first highlighted by Koitabashi et al. ${ }^{[6]}$ until the publication of that study, there had been no data about lower back or paravertebral region involvement in FG patients. They emphasized that spinal anaesthesia should not be applied in the presence of lumbar subcutaneous gas. ${ }^{[6]}$ The current study is the most extensive study to have evaluated the role of CT in the selection of the anaesthesia method. In the preoperative period, 87 (77\%) of the current study patients underwent tomographic examination. Of the patients applied with CT, spinal anaesthesia was selected for 53 (46.9\%) and general anaesthesia for 34 (30.1\%). When the CT images were examined of the patients in the general anaesthesia group, there was no paravertebral area involvement in any patient, but in $40 \%$ there were reported to be lesion areas of heterogenous soft tissue density observed as air values starting from the perianal region and continuing along the gluteal sulcus and within one or both of

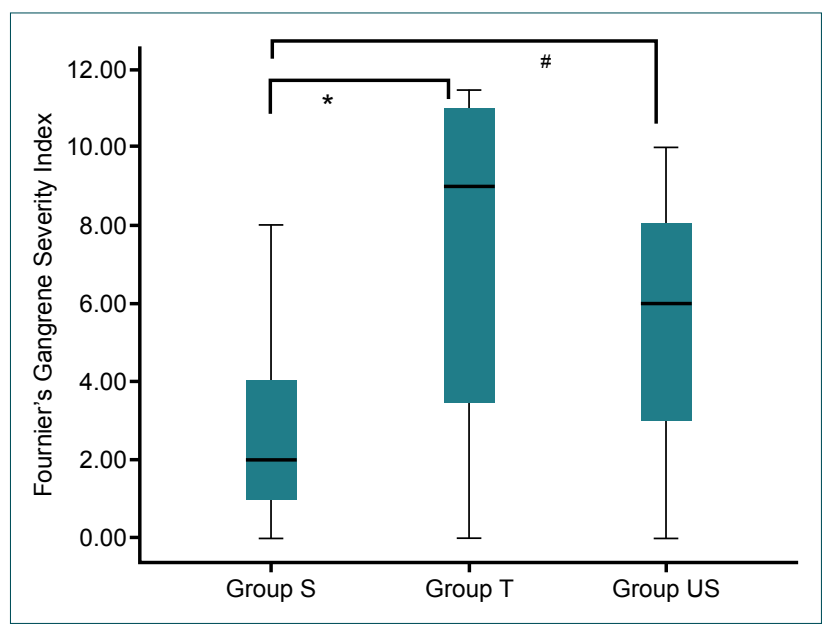

Figure 1. Fourniers Gangrene Severity Index. the right or left gluteal areas extending to the subcutaneous tissue. It was seen that spinal or local anaesthetic was not applied to any patient showing gluteal region extension. In the evaluation of the factors related to general anaesthesia, there was seen to be a strong correlation between the selection of general anaesthesia and the presence of gluteal involvement $(r=0.628, p<0.001)$.

The presence of sepsis was seen to be an independent factor related to the selection of anaesthesia method $(r=0.482$, $p=0.001)$. The primary aim of an anaesthetist in the intraoperative period is to provide safe and optimal care to be able to obtain the maximum benefit from the surgery to septic patients and the radiological source control procedure. ${ }^{[23]}$ Sato et al. ${ }^{[7]}$ emphasised that if there is sepsis in the table of FG patients or concomitant septic shock or hemodynamic instability, general anaesthesia should be selected for these patients. However, there is no ideal anaesthetic agent for patients in septic shock. The selected agents should be administered at small doses incrementally according to the patient response. ${ }^{[23]}$ In the current study, propofol and fentanyl were used with titration as intravenous agents in anaesthesia induction and rocuronium or atracurium as muscle relaxants. TIVA anaesthesia was used in $68.6 \%$ of the patients in anaesthesia maintenance.

In some recent studies, it has been emphasised that in patients where TIVA anaesthesia was used rather than sevoflurane in breast and colorectal cancer, there was a positive effect on survival through less depression of immune system functions. ${ }^{[24,25]}$ Furthermore, in two recent randomised, controlled studies, in the comparison of the application of propofol anaesthesia and paravertebral block for postoperative analgesia with sevoflurane and opioids in patients operated on for breast cancer, there was seen to be less loss of natural killer cell functions in patients following propofol anaesthesia. ${ }^{[26,27]}$

In the current study, spinal anaesthesia was preferred for patients with no bleeding diathesis or septic table, no infection in the area where spinal anaesthesia was to be applied and who were hemodynamically stable. In studies presenting anaesthesia experience in FG patients, $\mathrm{Kim},{ }^{[5]} \mathrm{Koitabashi,}{ }^{[6]}$ and Sato ${ }^{[7]}$ reported that spinal anaesthesia was preferred in cases with no infection in the area where spinal anaesthesia was to be applied and no hemodynamic instability. The indications for the selection of the anaesthesia method in the current study were seen to be similar to previous findings in the literature.

Although in the main aim of the current study, there was no effect on the biochemical, hematological and inflammatory parameters of the anaesthesia methods used, there was seen to be a significant decrease in the CRP and WBC levels in the postoperative period in the patients applied with spinal anaesthesia. A significant elevation was observed in the inflam- 
matory parameters (CRP, WBC), BUN and creatinine values in the patients applied with general anaethesia. In a study conducted by Malan, it was reported that sevoflurane could have a negative effect on renal functions. ${ }^{[28]}$ However, this is also a condition that can be encountered associated with a septic shock table or spread of the disease. ${ }^{[23]}$ For the evaluation of this in the current study, Group T and Group US were evaluated regarding patients with sepsis and total FGSI scores. No difference was determined between the groups regarding the preoperative presence of septic table $(p=0.558)$, and when evaluated regarding total FGSI scores, Group US were deter-

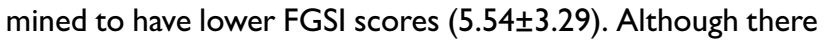
is no other study that has evaluated the effects of the use of TIVA and ultiva-sevoflurane on inflammatory parameters in FG patients, Nakanuno et al. ${ }^{[29]}$ reported that CRP values were lower postoperatively in patients where propofol was used as the anaesthetic agent compared to patients where sevoflurane anaesthesia was used. The results of the current study were seen to be consistent with the literature regarding both kidney functions and inflammatory parameters.

The most important limitation of this study was that as it was retrospective, it was dependent on the quality of the documentation kept in the ICU. However, patient records have been kept in great detail in our clinic, especially for the last 10 years, both in the computerised system and as nurses' observation forms, so the data loss can be considered to be at a minimum level. However, this type of study conducted prospectively would enable the more objective testing of immune functions in patients applied with general anaesthesia or spinal anaesthesia.

\section{Conclusion}

As a result, many factors should be considered in the selection of anesthesia methods in patients with FG. Our study showed that adequate debridement was successful with spinal anesthesia in patients with localized involvement in the scrotal region without gluteal region spread and who did not develop a septic table. Besides, it was shown that in cases of more extensive involvement and contraindication for spinal anesthesia (such as gluteal involvement or bleeding diathesis extending to the back) or septic patients, propofol as an induction agent, and isoflurane and sevoflurane as maintenance are titrated according to the patient's response in small doses to be used safely. However, prospective studies involving more patients on the subject should be conducted.

Ethics Committee Approval: This study was approved by the Kahramanmaras Sutcu Imam University Faculty of Medicine Clinical Research Ethics Committee (Approval number: 2019-04-12, date: 06.03.2019).

Peer-review: Internally peer-reviewed.

Authorship Contributions: Concept: O.F.B., B.K., V.F.P.; Design: O.F.B., B.K., V.F.P.; Supervision: O.F.B.; Fundings: O.F.B.; Materials: O.F.B., M.B., E.B.; Data: O.F.B., B.K., V.F.P.; M.B., E.B.,
M.B.B, O.B., M.K.D., H.Ç.; Analysis: O.F.B., B.K.; Literature search: O.F.B.; Writing: O.F.B., B.K., V.F.P.; M.B.; Critical revision: O.F.B., B.K., V.F.P.; M.B., E.B., M.B.B, O.B., M.K.D., H.Ç.

Conflict of Interest: None declared.

Financial Disclosure: The authors declared that this study has received no financial support.

\section{REFERENCES}

1. Aslanidis T, Myrou A, Giannakou-Peftoulidou M. Management of a young female patient with Fournier's gangrene and Lemierre's syndrome. Pan Afr Med J 2014;18:275. [CrossRef]

2. Singh A, Ahmed K, Aydin A, Khan MS, Dasgupta P. Fournier's gangrene. A clinical review. Arch Ital Urol Androl 2016;88:157-64. [CrossRef]

3. McCormack M, Valiquette AS, Ismail S. Fournier's gangrene: A retrospective analysis of 26 cases in a Canadian hospital and literature review. Can Urol Assoc J 2015;9:E407-10. [CrossRef]

4. Sorensen MD, Krieger JN. Fournier's Gangrene: epidemiology and outcomes in the general us population. Urol Int 2016;97:249-59. [CrossRef]

5. Kim TK, Yoon JR, Bae YK. Anesthetic experience of patients with Fournier's syndrome. Korean J Anesthesiol 2011;61:171-2. [CrossRef]

6. Koitabashi T, Umemura N, Takino Y. A case of Fournier's gangrene contraindicating spinal anesthesia. Anesthesiology 2000;92:289-90. [CrossRef]

7. Sato R, Tomioka T, Orii R, Yamada Y. Anesthetic management of four patients with Fournier syndrome. [Article in Japanese]. Masui 2008;57:355-7.

8. Guštin D. Sepsis in surgical patient. [Article in Croatian]. Acta Med Croatica 2015;69:161-6.

9. Enlund M, Berglund A, Andreasson K, Cicek C, Enlund A, Bergkvist L. The choice of anaesthetic--sevoflurane or propofol--and outcome from cancer surgery: a retrospective analysis. Ups J Med Sci 2014;119:251-61.

10. Laor E, Palmer LS, Tolia BM, Reid RE, Winter HI. Outcome prediction in patients with Fournier's gangrene. J Urol 1995;154:89-92. [CrossRef]

11. Canbaz H, Çağlıkülekçi M, Altun U, Dirlik M, Türkmenoğlu Ö, Taşdelen $\mathrm{B}$, et al. Fournier gangrene: Evaluation of risk factors and treatment cost-effectiveness of 18 cases. Ulus Travma Acil Cerrahi Derg 2010;16:71-6.

12. Clayton MD, Fowler JE Jr, Sharifi R, Pearl RK. Causes, presentation and survival of fifty-seven patients with necrotizing fasciitis of the male genitalia. Surg Gynecol Obstet 1990;170:49-55.

13. Yuki K, Murakami N. Sepsis pathophysiology and anesthetic consideration. Cardiovasc Hematol Disord Drug Targets 2015;15:57-69. [CrossRef]

14. Benjelloun el B, Souiki T, Yakla N, Ousadden A, Mazaz K, Louchi A, et al. Fournier's gangrene: our experience with 50 patients and analysis of factors affecting mortality. World J Emerg Surg 2013;8:13. [CrossRef]

15. Sen H, Bayrak O, Erturhan S, Borazan E, Koc MN. Is hemoglobin A1c level effective in predicting the prognosis of Fournier gangrene?. Urol Ann 2016;8:343-7. [CrossRef]

16. Dahm P, Roland FH, Vaslef SN, Moon RE, Price DT, Georgiade GS, et al. Outcome analysis in patients with primary necrotizing fasciitis of the male genitalia. Urology 2000;56:31-5; discussion 35-6. [CrossRef]

17. Sorensen MD, Krieger JN, Rivara FP, Klein MB, Wessells H. Fournier's gangrene: management and mortality predictors in a population based study. J Urol 2009;182:2742-7. [CrossRef]

18. Erol B, Tuncel A, Hanci V, Tokgoz H, Yildiz A, Akduman B, et al. Fournier's gangrene: overview of prognostic factors and definition of new prognostic parameter. Urology 2010;75:1193-8. [CrossRef]

19. Tuncel A, Aydin O, Tekdogan U, Nalcacioglu V, Capar Y, Atan A. 
Fournier's gangrene: three years of experience with 20 patients and validity of the fournier's gangrene severity index score. Eur Urol 2006;50:838-43. [CrossRef]

20. Janane A, Hajji F, Ismail TO, Chafiqui J, Ghadouane M, Ameur A, et al. Hyperbaric oxygen therapy adjunctive to surgical debridement in management of Fournier's gangrene: usefulness of a severity index score in predicting disease gravity and patient survival. [Article in Spanish]. Actas Urol Esp 2011;35:332-8. [CrossRef]

21. Amendola MA, Casillas J, Joseph R, Antun R, Galindez O. Fournier's gangrene: CT findings. Abdom Imaging 1994;19:471-4. [CrossRef]

22. Levenson RB, Singh AK, Novelline RA. Fournier gangrene: role of imaging. Radiographics 2008;28:519-28. [CrossRef]

23. Eissa D, Carton EG, Buggy DJ. Anaesthetic management of patients with severe sepsis. Br J Anaesth 2010;105:734-43. [CrossRef]

24. Lee JH, Kang SH, Kim Y, Kim HA, Kim BS. Effects of propofol-based total intravenous anesthesia on recurrence and overall survival in patients after modified radical mastectomy: a retrospective study. Korean J Anesthesiol 2016;69:126-32. [CrossRef]
25. Wigmore TJ, Mohammed K, Jhanji S. Long-term survival for patients undergoing Volatile Versus IV anesthesia for cancer surgery: A Retrospective analysis. Anesthesiology 2016;124:69-79. [CrossRef]

26. Desmond F, McCormack J, Mulligan N, Stokes M, Buggy DJ. Effect of anaesthetic technique on immune cell infiltration in breast cancer: a follow-up pilot analysis of a prospective, randomised, investigator-masked study. Anticancer Res 2015;35:1311-9.

27. Buckley A, McQuaid S, Johnson P, Buggy DJ. Effect of anaesthetic technique on the natural killer cell anti-tumour activity of serum from women undergoing breast cancer surgery: a pilot study. Br J Anaesth 2014;113:156-62. [CrossRef]

28. Malan TP Jr. Sevoflurane and renal function. Anesth Analg 1995;81:S3945. [CrossRef]

29. Nakanuno R, Yasuda T, Hamada H, Yoshikawa H, Nakamura R, Saeki $\mathrm{N}$, et al. Propofol for anesthesia and postoperative sedation resulted in fewer inflammatory responses than sevoflurane anesthesia and midazolam sedation after thoracoabdominal esophagectomy. Hiroshima J Med Sci 2015;64:31-7.

\title{
ORIJINAL ÇALIŞMA - ÖZ
}

\section{Peroneal nekrotizan fasiit hastalığında anestezi tekniğini seçerken kullanılması gereken faktörler var mı ?: İki merkezden bir kohortun tanımlayıcı analizi \\ Dr. Ömer Faruk Boran, ${ }^{1}$ Dr. Bülent Katı, ${ }^{2}$ Dr. Veli Fahri Pehlivan, ${ }^{3}$ Dr. Maruf Boran, ${ }^{4}$ Dr. Evren Büyükfırat, ${ }^{3}$ Dr. Mehmet Buğra Bozan, ${ }^{5}$ Dr. Osman Barut, ${ }^{6}$ Dr. Mehmet Kutlu Demirkol, ${ }^{6}$ Dr. Halil Çiftçi ${ }^{2}$}

\author{
${ }^{1}$ Kahramanmaraş Sütçü İmam Üniversitesi Tıp Fakültesi, Anestezi ve Reanimasyon Anabilim Dalı, Kahramanmaraş \\ ${ }^{2}$ Harran Üniversitesi Tıp Fakültesi, Üroloji Anabilim Dalı, Şanlıurfa \\ ${ }^{3}$ Harran Üniversitesi Tıp Fakültesi, Anestezi ve Reanimasyon Bölümü Anabilim Dalı, Şanlıurfa \\ ${ }^{4}$ Amasya Şerefeddin Sabuncuoğlu Eğitim ve Araştırma Hastanesi, Yoğum Bakım Ünitesi, Amasya \\ ${ }^{5}$ Kahramanmaraş Sütçü İmam Üniversitesi Tıp Fakültesi, Genel Cerrahi Anabilim Dalı, Kahramanmaraş \\ ${ }^{6}$ Kahramanmaraş Sütçü İmam Üniversitesi Tıp Fakültesi, Üroloji Anabilim Dalı, Kahramanmaraş
}

AMAÇ: Mevcut çalışmada özellikli bir hastalık grubu olan Fournier's gangrenli hastalarda kullanılacak anestezik yöntem seçiminde etki eden faktörlerin incelenmesi ve literatür eşliğinde tartışılması amaçlanmıştır.

GEREÇ VE YÖNTEM: Ocak 20 I4-Mayıs 2019 yılları arasında Fournier's gangreni nedeniyle ameliyat edilen I I 3 hasta geriye dönük olarak değerlendirildi. Yetmiş sekiz hastanın spinal anestezi (Grup S), 35 hastanın ise genel anestezi (Grup G) ile ameliyat edildiği görüldü. Hastalar yaş, cinsiyet, kullanılan anestezi yöntemi (spinal, genel), uygulanan anestezik ajan sepsis varlığı, biyokimyasal, hematolojik ve enflamatuvar parametreler gibi bilgiler açısından değerlendirildi.

BULGULAR: Çalışmaya alınan hastaların FGSI skorları açısından değerlendirildiğinde de grup I'deki hastaların daha düşük değerlere sahip oldukları görüldü $(p=0.00$ I). Ameliyat öncesi dönemde hastaların 87 'sine (\%77) tomografik inceleme yapıldığı görüldü. Hastaların tomografik görüntüleri incelendiğinde genel anestezi uygulanan hastalardan I3'ünde (\%37.I) sağ/sol gluteal alandan birisi ya da her ikisinde de bulunan ve cilt altı dokuya dek uzanan içerisinde hava değerleri izlendiği görüldü. Genel anestezi seçimine etki eden faktörler incelendiğinde FGSI değerindeki artışın ( $r=0.482$, $p=0.00 \mathrm{I})$, sepsis varlığı ile $(r=0.485, p=0.00 \mathrm{I})$ ve gluteal bölge tutulumu ile $(r=0.628, p<0.00 \mathrm{I})$ pozitif yönde korelasyon izlenirken platelet değerlerindeki düşüşle de spinal anestezi uygulaması arasında ilişki olduğu görüldü $(r=0.238, p=0.01 \mathrm{I})$.

TARTIŞMA: Fournier's gangrenli hastalarda anestezi yöntem seçimi hastanın genel durumu, sepsis varlı̆ı, kanama dizatezi bulunup bulunmaması, gibi faktörlerin yanı sıra FGSI indeksi ve tomografik olarak gluteal bölge tutulumu gibi pek çok faktörün etkilediği kompleks bir durum olup anestezi yöntem tercihinde hastaların risk-fayda dengesinin bireysel olarak değerlendirilmesi gerekmektedir.

Anahtar sözcükler: Anestezi yönetimi; Fournier's gangreni; sevofluran; TIVA; ultiva.

Ulus Travma Acil Cerrahi Derg 2022;28(I):48-56 doi: 10.14744/tjtes.2020.15088 